[Chem. Pharm. Bull.

35(10)4307-4313(1987)

\title{
Synthesis and Analgesic Activity of C-Terminal Fragment Peptides of Cholecystokinin ${ }^{1)}$
}

\author{
Koji Iuchi, ${ }^{*}$ Masahiro Nitta, Takashi Tanaka, Keizo Ito, \\ YASUO MORIMOTO and Goro TSUKamoto
}

Pharmaceuticals Research Center, Kanebo Ltd., Tomobuchi-cho,

Miyakojima-ku, Osaka 534, Japan

(Received December 5, 1986)

\begin{abstract}
Eleven C-terminal fragment peptides of cholecystokinin (CCK) which contain a O-sulfated tyrosine residue $[\mathrm{CCK}(27-32), \mathrm{CCK}(27-31), \mathrm{CCK}(27-31)$ amide, CCK $(27-30)$, CCK $(27-$ 30)amide, CCK(27-29), CCK(27-29)amide, CCK(26-27), CCK(26-27)amide, CCK(25-27) and CCK (25-27)amide] were prepared by the solution method. The syntheses of these peptides were carried out by stepwise condensation in combination with fragment condensation. Analgesic effects of these fragment peptides were measured by means of the writhing test. The $\mathrm{ED}_{50}$ value of CCK (27-32) was $9.1 \mathrm{mg} / \mathrm{kg}$ and that of CCK (25-27) was $7.5 \mathrm{mg} / \mathrm{kg}$, but the other synthetic peptides produced no statistically significant response at a dose of 8 or $10 \mathrm{mg} / \mathrm{kg}$.
\end{abstract}

Keywords—cholecystokinin (CCK); C-terminal CCK fragment peptide; peptide synthesis; O-sulfated tyrosine residue; $\operatorname{CCK}(27-32)$; $\operatorname{CCK}(25-27)$; writhing test; analgesic effect

Zetler ${ }^{2)}$ reported that cholecystokinin octapeptide (CCK-8) and caerulein produced potent analgesic effects after subcutaneous injection in mice. In our previous study ${ }^{3)}$ on some C-terminal CCK-related peptides, it was found that CCK-7 [H-Tyr $\left(\mathrm{SO}_{3} \mathrm{H}\right)-\mathrm{Met}-\mathrm{Gly}-\mathrm{Trp}-$ Met-Asp-Phe- $\mathrm{NH}_{2}$ ] produced analgesic effect, and the $\mathrm{O}$-sulfated tyrosine residue was considered to be essential for this effect. However, excepting the finding that $\mathrm{CCK}(27-$ 32)amide did not show analgesic effect at a dose of $8 \mathrm{mg} / \mathrm{kg},{ }^{3)}$ there exists no information on analgesic effects of CCK-related peptides which are smaller than CCK-7 and contain a sulfate residue at the $\mathrm{N}$-terminal or $\mathrm{C}$-terminal. In order to obtain such information, we intended to synthesize eleven C-terminal fragment peptides of $\operatorname{CCK}[\operatorname{CCK}(27-32), \operatorname{CCK}(27-31)$, CCK(27-31)amide, CCK(27-30), CCK(27-30)amide, CCK(27-29), CCK(27-29)amide, $\operatorname{CCK}(26-27), \operatorname{CCK}(26-27)$ amide, $\operatorname{CCK}(25-27)$ and $\operatorname{CCK}(25-27)$ amide] by the solution method, and to examine their analgesic effects using the writhing method according to the procedure of Zetler. ${ }^{2)}$ The synthesis of these peptides except CCK (27-29) and CCK(2627)amide has not been reported. $\operatorname{CCK}(27-29)$ has been synthesized by Kádár et al ${ }^{4)}$ in their study on the structure-activity relationships of anticonvulsive activity of CCK-8, but the synthetic method was not reported in detail. CCK (26-27)amide has been synthesized by Crawley et al..$^{5}$ by the solid-phase method in their study on the behavioral activity of C-and $\mathrm{N}$-terminal fragments of CCK-8. The present report deals with the synthesis of eleven Cterminal fragment peptides of $\mathrm{CCK}$ and the determination of their analgesic effects.

The synthetic scheme for $\mathrm{CCK}(27-32)$ [H-Tyr $\left(\mathrm{SO}_{3}{ }^{-}\right)$-Met-Gly-Trp-Met-Asp-OH] is shown in Fig. 1.

The $\alpha$-amino functions of amino acid residues and peptides were protected with the Boc group. The two carboxyl groups of the aspartic acid residue at the C-terminal were protected as methyl esters. The C-terminal peptide fragment, Boc-Met-Asp(OMe)-OMe (I) was prepared by the coupling of $\left.\mathrm{H}-\mathrm{Asp}(\mathrm{OMe})-\mathrm{OMe}^{6}\right)$ with Boc-Met-OCp. ${ }^{7)}$ Boc-Met-Gly-TrpOMe (II) was synthesized by the coupling of Boc-Met-Gly-OH ${ }^{3)}$ with $\mathrm{H}-\mathrm{Trp}-\mathrm{OMe}^{8)}$ using 


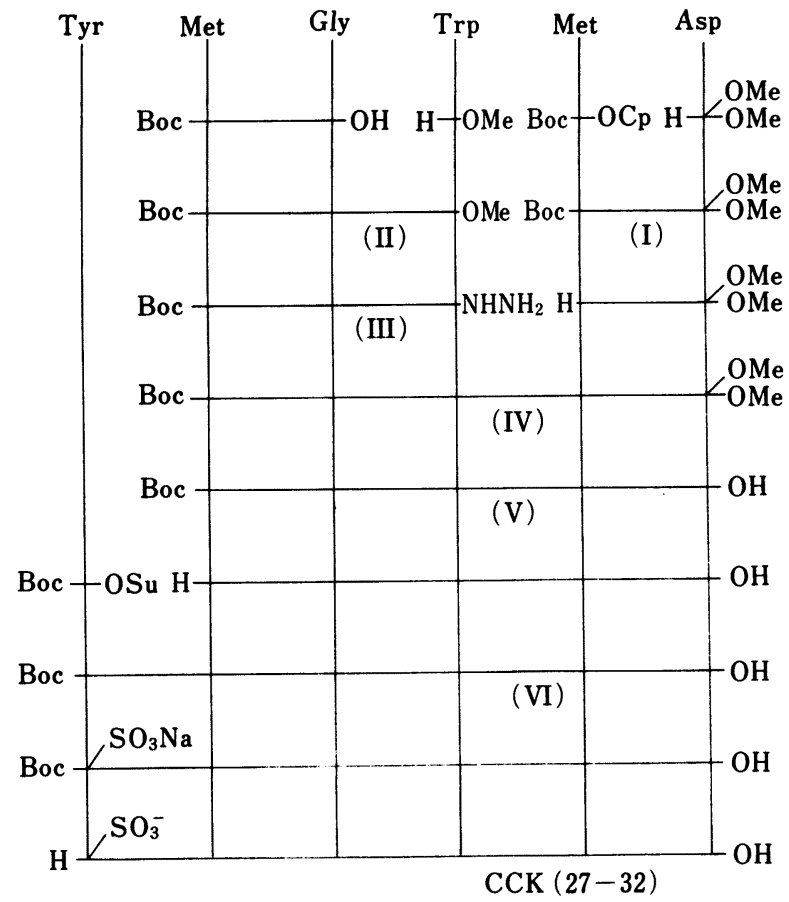

Fig. 1. Synthetic Scheme for CCK (27-32)

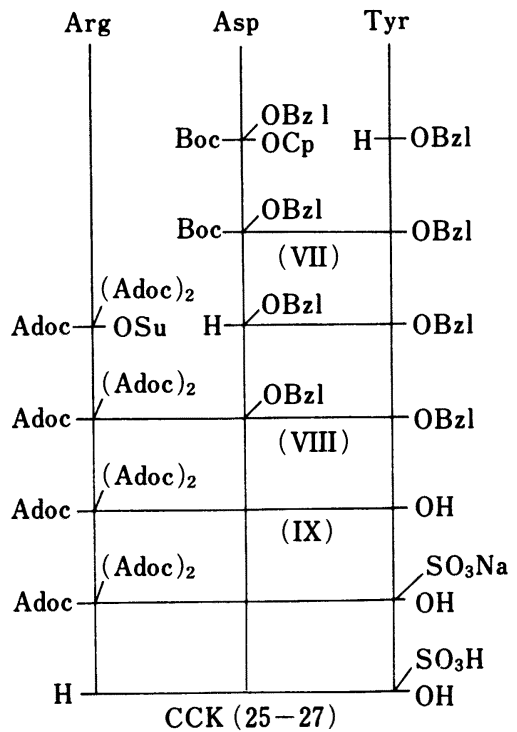

Fig. 2. Synthetic Scheme for CCK (25-27)

DCC in the presence of HOBt, then converted to the corresponding hydrazide (III) by treatment with hydrazine hydrate. After deprotection of the Boc group of I with TFA, the resulting $\mathrm{H}-\mathrm{Met}-\mathrm{Asp}(\mathrm{OMe})-\mathrm{OMe}$ was condensed with hydrazide III by the azide procedure to afford the Boc-protected pentapeptide dimethyl ester (IV), which was saponified to produce Boc-Met-Gly-Trp-Met-Asp-OH (V). This compound V was deprotected with TFA, and a tyrosine residue was linked at the $\mathrm{N}$-terminal using Boc-Tyr-OSu${ }^{9}$ to afford Boc-Tyr-MetGly-Trp-Met-Asp-OH (VI). Compound VI was sulfated with pyridine-sulfur trioxide complex $^{10)}$ in anhydrous pyridine solution, and then treated with sodium carbonate. Deprotection of the Boc group with TFA provided crude $\mathrm{CCK}(27-32)$, which was purified by column chromatography on diethylaminoethyl (DEAE) Sephadex A-25 using a linear gradient of aqueous ammonium carbonate solution as the eluting solvent, and lyophilized.

The synthetic scheme for $\mathrm{CCK}(25-27)$ [ $\left.\mathrm{H}-\mathrm{Arg}-\mathrm{Asp}-\mathrm{Tyr}\left(\mathrm{SO}_{3}{ }^{-}\right)-\mathrm{OH}\right]$ is outlined in Fig.

\section{2.}

The C-terminal carboxyl group of the tyrosine residue and the $\beta$-carboxyl group of the aspartic acid residue were protected as benzyl esters. However, these benzyl groups were removed by catalytic hydrogenolysis before sulfation, because the removal of these protecting groups by catalytic hydrogenolysis after sulfation was considered to be hindered by the negative catalysis of the sulfur atom of the sulfate. The $\alpha$-amino function and the guanidino function of the arginine residue were protected with the Adoc groups, in order to increase the solubility of protected $\mathrm{CCK}(25-27)$ and in order to have protecting groups that could be removed under mild acidic conditions. $\mathrm{H}-\mathrm{Tyr}-\mathrm{OBzl}{ }^{11)}$ was coupled with Boc-Asp(OBzl)OCp to obtain Boc-Asp(OBzl)-Tyr-OBzl (VII). After removal of the N-terminal Boc-group of VII, an arginine residue was linked using $\mathrm{Adoc}-\mathrm{Arg}(\mathrm{Adoc})_{2}-\mathrm{OSu}^{12)}$ to produce the tripeptide derivative (VIII). Catalytic hydrogenolysis of VIII produced the Adoc-tripeptide deriva- 
TABLE I. Analgesic Effect of CCK-Related Peptides

\begin{tabular}{|c|c|c|c|}
\hline Peptides & $\begin{array}{c}\text { Dose } \\
\mathrm{mg} / \mathrm{kg} \text {, s.c. }\end{array}$ & $\begin{array}{c}\text { Number of } \\
\text { mice }\end{array}$ & $\begin{array}{c}\text { Writhing }(\%) \\
\text { mean } \pm \text { S.E. }\end{array}$ \\
\hline \multirow[t]{3}{*}{$\operatorname{CCK}(27-32)$} & 2.5 & 6 & $90.9 \pm 19.2$ \\
\hline & 5 & 6 & $72.7 \pm 8.1$ \\
\hline & 10 & 6 & $45.5 \pm 12.1^{a)}$ \\
\hline $\operatorname{CCK}(27-31)$ & 10 & 5 & $82.8 \pm 13.8$ \\
\hline CCK $(27-31)$ amide & 10 & 5 & $86.2 \pm 17.2$ \\
\hline $\operatorname{CCK}(27-30)$ & 10 & 5 & $91.0 \pm 14.2$ \\
\hline $\operatorname{CCK}(27-30)$ amide & 10 & 5 & $89.6 \pm 15.7$ \\
\hline $\operatorname{CCK}(27-29)$ & 8 & 5 & $67.5 \pm 6.0$ \\
\hline $\mathrm{CCK}(27-29)$ amide & 8 & 5 & $72.3 \pm 16.9$ \\
\hline $\operatorname{CCK}(26-27)$ & 10 & 6 & $109.3 \pm 21.3$ \\
\hline CCK $(26-27)$ amide & 10 & 6 & $67.6 \pm 11.1$ \\
\hline \multirow[t]{3}{*}{$\operatorname{CCK}(25-27)$} & 2.5 & 6 & $106.3 \pm 17.7$ \\
\hline & 5 & 6 & $62.5 \pm 19.8$ \\
\hline & 10 & 6 & $39.6 \pm 10.4^{b)}$ \\
\hline CCK $(25-27)$ amide & 10 & 6 & $72.3 \pm 12.8$ \\
\hline $\operatorname{CCK}(27-32)$ amide & 10 & 6 & $72.9 \pm 11.4$ \\
\hline
\end{tabular}

a) $p<0.05, b) p<0.01$ ( $t$-test).

tive (IX). Compounds IX was sulfated, treated with sodium carbonate, and than Adoc groups were removed with TFA to afford crude $\operatorname{CCK}(25-27)$, which was purified by DEAE Sephadex A-25 column chromatography.

CCK (27-31), CCK (27-31)amide, CCK(27-30), CCK(27-30)amide, CCK(27-29), $\operatorname{CCK}(27-29)$ amide, $\operatorname{CCK}(26-27), \operatorname{CCK}(26$ - 27)amide and $\operatorname{CCK}(25-27)$ amide were synthesized analogously.

The eleven CCK-related peptides thus synthesized were shown to be homogeneous by thin-layer chromatography (TLC) on silica gel. Elemental analyses and amino acid analyses of acid hydrolysates of these peptides were in good agreement with the theoretically expected values. In the infrared (IR) spectra of these CCK-related peptides, the characteristic band $\left(1050 \mathrm{~cm}^{-1}\right)^{10)}$ due to a sulfate ester was observed.

The analgesic effects of these eleven CCK-related peptides and CCK(27-32)amide ${ }^{3)}$ were examined by means of the writhing test according to Zetler. ${ }^{2)}$ Writhing was elicited by intraperitoneal injection of $0.6 \%(\mathrm{v} / \mathrm{v})$ acetic acid $(10 \mathrm{ml} / \mathrm{kg})$ into ddY male mice weighing 18 $22 \mathrm{~g}$. Solutions of the peptides in distilled water or $0.05 \mathrm{M}$ sodium bicarbonate were administered subcutaneously $10 \mathrm{~min}$ before the acetic acid injection. The number of writhings occurring between 10 and $20 \mathrm{~min}$ after injection of acetic acid was counted. Data were expressed as the ratio ( $\%$ ) with respect to the control value (Table I). CCK $(27-32)$ and $\mathrm{CCK}(25-27)$ reduced the number of writhings dose-dependently and the $\mathrm{ED}_{50}$ values were calculated from the regression analysis of the dose-response curves to be 9.1 and $7.5 \mathrm{mg} / \mathrm{kg}$, respectively. The other synthetic CCK-related peptides gave no statistically significant response at a dose of 10 or $8 \mathrm{mg} / \mathrm{kg}$ [in the case of $\operatorname{CCK}(27-29)$ and $\operatorname{CCK}(27-29)$ amide].

In the present study, small peptides, $\operatorname{CCK}(27-32)$ and $\operatorname{CCK}(25-27)$ were found to retain the analgesic effect $\left(\mathrm{ED}_{50}=9.1,7.5 \mathrm{mg} / \mathrm{kg}\right.$, respectively), notwithstanding the fact that the other synthetic CCK-related peptides produced no statistically significant response at a dose of 8 or $10 \mathrm{mg} / \mathrm{kg}$. These phenomena are very interesting, since they seem to suggest that two active centers for analgesic effect exist in the C-terminal of CCK and that structural change at the C-terminal of these active centers is reflected in the analgesic activity. 


\section{Experimental}

In order to prevent oxidation of the methionine residue, every reaction was performed under a nitrogen atmosphere and peroxide-free ether stored over ferrous sulfate was used. ${ }^{13)}$ The melting points are uncorrected. Optical rotations were measured with a DIP-181 polarimeter (Japan Spectroscopic Co.). Amino acid analyses of acid hydrolysates were performed with a JEOL JLC-6AH amino acid analyzer. IR spectra were measured with a Shimadzu IR-400 infrared spectrophotometer. Elementary analyses were carried out with a Yanagimoto MT-3 CHN Corder. Ascending TLC was performed on a silica gel TLC plate (Kieselgel $60 \mathrm{~F}_{254}$, Merck) using the following solvent systems: $R f^{1} n$-BuOH-AcOH-pyridine- $\mathrm{H}_{2} \mathrm{O}(4: 1: 1: 2) ; R f^{2}$ AcOEt-pyridine-AcOH- ${ }_{2} \mathrm{O}(60: 20: 6: 11)$; $R f^{3} n$-BuOH-AcOH-pyridine- $\mathrm{H}_{2} \mathrm{O}(30: 20: 6: 24) ; R f^{4} n$ - $\mathrm{BuOH}-\mathrm{AcOH}-$ pyridine- $\mathrm{H}_{2} \mathrm{O}(60: 20: 6: 24) ; R f^{5} \mathrm{AcOEt}$; $R f^{6} \mathrm{CHCl}_{3}-$ AcOEt $(2: 1) ; R f^{7}$ ether.

Boc-Met-Asp(OMe)-OMe (I)- $-\mathrm{Et}_{3} \mathrm{~N}(0.7 \mathrm{ml})$ was added to a solution of $\mathrm{H}-\mathrm{Asp}(\mathrm{OMe})-\mathrm{OMe} \cdot \mathrm{HCl}^{6)}(988 \mathrm{mg})$ in DMF $(10 \mathrm{ml})$ at $0^{\circ} \mathrm{C}$ and the mixture was stirred for $30 \mathrm{~min}$, then Boc-Met-OCp ${ }^{7}(2.04 \mathrm{~g})$ was added and stirring was continued for $3 \mathrm{~d}$ at $8{ }^{\circ} \mathrm{C}$. The solvent was evaporated off in vacuo. The residue was dissolved in AcOEt (150 ml). This solution was washed successively with $5 \%$ sodium bicarbonate $(2 \times 50 \mathrm{ml}), 5 \%$ citric acid $(2 \times 50 \mathrm{ml})$ and brine $(2 \times 50 \mathrm{ml})$, and then dried over $\mathrm{Na}_{2} \mathrm{SO}_{4}$. After evaporation of the solvent in vacuo, the residue $(2.8 \mathrm{~g})$ was purified by silica gel column chromatography (Kieselgel 60, Merck, $100 \mathrm{~g}$ ) with $\mathrm{AcOEt}-\mathrm{CHCl}_{3}(2: 1)$ as the eluent and the product was crystallized with AcOEt-petroleum ether. Yield $1.4 \mathrm{~g}(75 \%), \mathrm{mp} 64.5-66^{\circ} \mathrm{C},[\alpha]_{\mathrm{D}}^{21}-20.0(c=1.0$, $\mathrm{MeOH}), R f^{1} 0.78, R f^{5} 0.62, R f^{6}$ 0.50. Anal. Calcd for $\mathrm{C}_{16} \mathrm{H}_{28} \mathrm{~N}_{2} \mathrm{O}_{7} \mathrm{~S}: \mathrm{C}, 48.97 ; \mathrm{H}, 7.19 ; \mathrm{N}, 7.14$. Found: C, 49.02; $\mathrm{H}$, $7.14 ; \mathrm{N}, 7.25$.

Boc-Met-Gly-Trp-OMe (II) $-\mathrm{Et}_{3} \mathrm{~N}(1.4 \mathrm{ml})$ was added to a solution of $\mathrm{H}-\mathrm{Trp}-\mathrm{OMe} \cdot \mathrm{HCl}^{8)}(2.55 \mathrm{~g})$ at $0{ }^{\circ} \mathrm{C}$. The mixture was stirred for $30 \mathrm{~min}$, then Boc-Met-Gly-OH ${ }^{3)}(3.06 \mathrm{~g})$, HOBt $(1.35 \mathrm{~g})$ and DCC $(2.27 \mathrm{~g})$ were added. The whole was stirred overnight at $8{ }^{\circ} \mathrm{C}$, dicyclohexylurea was removed by filtration, and the solvent was evaporated off in vacuo. The residue was dissolved in AcOEt $(200 \mathrm{ml})$. This solution was washed successively with $5 \%$ sodium bicarbonate $(2 \times 50 \mathrm{ml}), 5 \%$ citric acid $(2 \times 50 \mathrm{ml})$ and brine $(2 \times 50 \mathrm{ml})$, and then dried over $\mathrm{Na}_{2} \mathrm{SO}_{4}$. The solvent was evaporated off in vacuo and the resulting residue was purified by silica gel column chromatography (Kieselgel, 60, Merck, $70 \mathrm{~g}$ ). The column was developed with AcOEt, and the desired fractions were collected. The solvent was evaporated off in vacuo to give a white powder. Yield $4.5 \mathrm{~g}(88.8 \%), \mathrm{mp} 45-47^{\circ} \mathrm{C}$ (soften), $[\alpha]_{\mathrm{D}}^{22}+33.6^{\circ}(c=1.0$, AcOEt), $R f^{2} 0.93, R f^{5} 0.37$. Amino acid ratio in an acid hydrolysate: Gly, 1.02; Met, 0.98 (average recovery, $99 \%$ ). Anal. Calcd for $\mathrm{C}_{24} \mathrm{H}_{34} \mathrm{~N}_{4} \mathrm{O}_{6} \mathrm{~S}$ : C, 56.90; H, 6.76; N, 11.06. Found: C, 56.96; H, 6.91; N, 10.88 .

Boc-Met-Gly-Trp-NHNH ${ }_{2}$ (III)_- Hydrazine hydrate $(1.5 \mathrm{~g})$ was added to a solution of II ( $\left.1.53 \mathrm{~g}\right)$ in $n$-PrOH $(10 \mathrm{ml})$. The mixture was left to stand at room temperature for $4 \mathrm{~d}$ to yield a precipitate. This was collected by filtration and recrystallized from $n$-PrOH. Yield $1.26 \mathrm{~g}\left(80^{\circ}\right), \mathrm{mp} 76-78^{\circ} \mathrm{C},[\alpha]_{\mathrm{D}}^{21}-11.9^{\circ}(c=1.0, \mathrm{MeOH}), R f^{1} 0.68$, $R f^{2}$ 0.74. Anal. Calcd for $\mathrm{C}_{23} \mathrm{H}_{34} \mathrm{~N}_{6} \mathrm{O}_{5} \mathrm{~S} \cdot \mathrm{H}_{2} \mathrm{O}: \mathrm{C}, 52.66 ; \mathrm{H}, 6.72 ; \mathrm{N}, 16.02$. Found: $\mathrm{C}, 52.97 ; \mathrm{H}, 6.52 ; \mathrm{N}, 15.96$.

Boc-Met-Gly-Trp-Met-Asp(OMe)-OMe (IV)_Compound I (1.89 g) was added to a solution of TFA (5 ml) containing thioanisole $(0.5 \mathrm{ml})$ at $0{ }^{\circ} \mathrm{C}$ and the mixture was stirred for $1 \mathrm{~h}$. Ether $(30 \mathrm{ml})$ was added to the mixture to cause a precipitate, which was collected by filtration, washed with ether $(50 \mathrm{ml})$ and dried over $\mathrm{KOH}$ in vacuo to give $\mathrm{H}$-Met-Asp(OMe)-OMe-TFA $(542 \mathrm{mg})$. On the other hand, $5.6 \mathrm{~N} \mathrm{HCl}$ in dioxane $(0.5 \mathrm{ml})$ and isoamyl nitrite $(0.14 \mathrm{ml})$ were added to a solution of III $(481 \mathrm{mg})$ in DMF $(18 \mathrm{ml})$ at $-50^{\circ} \mathrm{C}$, and the mixture was stirred at $-30-$ $-20^{\circ} \mathrm{C}$ for $30 \mathrm{~min}$ to prepare a solution of Boc-Met-Gly-Trp- $\mathrm{N}_{3}$. H-Met-Asp(OMe)-OMe $\cdot$ TFA (540 mg) was added to a solution of $\mathrm{Et}_{3} \mathrm{~N}(0.37 \mathrm{ml})$ in DMF $(10 \mathrm{ml})$ at $0^{\circ} \mathrm{C}$ and the mixture was added to the solution of Boc-MetGly-Trp- $\mathrm{N}_{3}$ at $-50^{\circ} \mathrm{C}$. The reaction mixture was stirred for $2 \mathrm{~d}$ at $8{ }^{\circ} \mathrm{C}$ and the solvent was evaporated off in vacuo. The residue was dissolved in AcOEt $(200 \mathrm{ml})$. The solution was washed successively with $5 \%$ citric acid $(2 \times 50 \mathrm{ml})$, $5 \%$ sodium bicarbonate $(2 \times 50 \mathrm{ml}), \mathrm{H}_{2} \mathrm{O}(2 \times 50 \mathrm{ml})$ and brine $(2 \times 50 \mathrm{ml})$, then dried over $\mathrm{Na}_{2} \mathrm{SO}_{4}$. Evaporation of the solvent in vacuo gave an amorphous residue, which was recrystallized from EtOH- $\mathrm{H}_{2} \mathrm{O}$. Yield $454 \mathrm{mg}(63.6 \%)$, $\operatorname{mp} 125-128^{\circ} \mathrm{C},[\alpha]_{\mathrm{D}}^{21}-27.5^{\circ}(c=1, \mathrm{MeOH}), R f^{1} 0.79, R f^{2} 0.84, R f^{3} 0.76$. Amino acid ratio in an acid hydrolysate: Asp, 1.03; Gly, 1.00; Met, 1.96 (average recovery $89 \%$ ). Anal. Calcd for $\mathrm{C}_{34} \mathrm{H}_{50} \mathrm{~N}_{6} \mathrm{O}_{10} \mathrm{~S}_{2} \cdot 0.5 \mathrm{H}_{2} \mathrm{O}: \mathrm{C}, 52.63 ; \mathrm{H}, 6.63$; $\mathrm{N}, 10.83$. Found: $\mathrm{C}, 52.70 ; \mathrm{H}, 6.50 ; \mathrm{N}, 10.91$.

Boc-Met-Gly-Trp-Met-Asp-OH (V)—A $1 \mathrm{~N} \mathrm{NaOH}$ solution $(1.54 \mathrm{ml})$ was added to a solution of IV $(537 \mathrm{mg})$ in $\mathrm{MeOH}(10 \mathrm{ml})$ and the mixture was stirred at room temperature for $5 \mathrm{~h}$. After evaporation of the solvent in vacuo, water $(50 \mathrm{ml})$ was added to the residue. The aqueous layer was washed with AcOEt $(2 \times 50 \mathrm{ml})$, acidified with citric acid and extracted with AcOEt $(3 \times 50 \mathrm{ml})$. The extract was washed with $\mathrm{H}_{2} \mathrm{O}(50 \mathrm{ml})$ and brine $(2 \times 50 \mathrm{ml})$, then dried over $\mathrm{Na}_{2} \mathrm{SO}_{4}$. The solvent was evaporated off in vacuo and the residue was recrystallized from EtOH- $\mathrm{H}_{2} \mathrm{O}$. Yield $327 \mathrm{mg}\left(64^{\%}\right), \mathrm{mp} 191-192^{\circ} \mathrm{C}(\mathrm{dec}),. R f^{1} 0.59, R f^{2} 0.37, R f^{3} 0.59,[\alpha]_{\mathrm{D}}^{22}-23^{\circ}(c=1, \mathrm{MeOH})$. Amino acid ratio in an acid hydrolysate: Asp, 1.03; Gly, 0.99; Met, 1.98 (average recovery, $92 \%$ ). Anal. Calcd for $\mathrm{C}_{32} \mathrm{H}_{46} \mathrm{~N}_{6} \mathrm{O}_{10} \mathrm{~S}_{2}$ : C, $52.02 ; \mathrm{H}, 6.28$; N, 11.37. Found: C, 52.31; H, 6.19; N, 11.44 .

Boc-Tyr-Met-Gly-Trp-Met-Asp-OH (VI) _ Compound V (270 mg) was treated with TFA to give the TF.A salt of the deprotected pentapeptide $\left(280 \mathrm{mg}, R f^{1} 0.42, R f^{2} 0.49\right)$ in the same manner as described for the deprotection of $I$ in the synthesis of IV. This product $(248 \mathrm{mg})$ was added to a solution of $\mathrm{Et}_{3} \mathrm{~N}(34 \mathrm{mg})$ in DMF $(5 \mathrm{ml})$ and the mixture was stirred at $0^{\circ} \mathrm{C}$ for $20 \mathrm{~min}$, then $\mathrm{Boc}-\mathrm{Tyr}-\mathrm{OSu}^{9}(125 \mathrm{mg})$ was added. The whole was stirred at 
$8{ }^{\circ} \mathrm{C}$ for $7 \mathrm{~d}$ and the solvent was evaporated off in vacuo. The residue was dissolved in AcOEt (150 ml). This solution was washed successively with $5 \%$ citric acid $(3 \times 50 \mathrm{ml}), \mathrm{H}_{2} \mathrm{O}(2 \times 50 \mathrm{ml})$ and brine $(2 \times 50 \mathrm{ml})$, then dried over $\mathrm{Na}_{2} \mathrm{SO}_{4}$. After evaporation of the solvent, the residue was applied to a Sephadex G-25 column $(3 \times 37 \mathrm{~cm})$. The column was equilibrated and developed with $0.05 \mathrm{M}$ ammonium carbonate. Fractions No. $10-16(15 \mathrm{ml}$ each $)$ were collected and lyophilized to give a white powder. This material was added to a solution of $3 \%$ citric acid and extracted with AcOEt $(100 \mathrm{ml})$. The extract was washed with $\mathrm{H}_{2} \mathrm{O}(2 \times 50 \mathrm{ml})$ and dried over $\mathrm{Na}_{2} \mathrm{SO}_{4}$. The solvent was evaporated off in vacuo and the residue was triturated with ether. Yield $205 \mathrm{mg}(64 \%), \mathrm{mp} 120-130^{\circ} \mathrm{C}\left(\mathrm{dec}\right.$.), $[\alpha]_{\mathrm{D}}^{20}$ $-19.0^{\circ}\left(c=1.4,1 \mathrm{~N} \mathrm{NH}_{4} \mathrm{OH}\right), R f^{1} 0.74, R f^{2} 0.36, R f^{3} 0.60$. Amino acid ratio in an acid hydrolysate: Asp, $1.00 ; \mathrm{Gly}$, 0.99; Met, 1.96; Tyr, 1.04 (average recovery, 90\%). Anal. Calcd for $\mathrm{C}_{41} \mathrm{H}_{55} \mathrm{~N}_{7} \mathrm{O}_{12} \mathrm{~S}_{2} \cdot 0.5 \mathrm{AcOEt} \cdot \mathrm{H}_{2} \mathrm{O}: \mathrm{C}, 53.57 ; \mathrm{H}$, $6.38 ; \mathrm{N}, 10.17$. Found: C, 53.81; H, 6.49; N, 10.19 .

CCK(27-32) [H-Tyr(SO ${ }_{3}^{-}$-Met-Gly-Trp-Met-Asp-OH] Pyridine-sulfur trioxide complex (130 mg) was added to a solution of VI $(150 \mathrm{mg})$ in anhydrous pyridine $(5 \mathrm{ml})$ and the mixture was stirred at $8{ }^{\circ} \mathrm{C}$ for $2 \mathrm{~d}$. After removal of the solvent in vacuo, a solution of $10 \%$ sodium bicarbonate solution $(10 \mathrm{ml})$ was added to the residue at $0{ }^{\circ} \mathrm{C}$ and the mixture was stirred for $30 \mathrm{~min}$. The aqueous layer was washed with $n-\mathrm{BuOH}(5 \mathrm{ml})$ and concentrated to about $5 \mathrm{ml}$ in vacuo. This was applied to a Sephadex G-25 column $(3 \times 37 \mathrm{~cm})$. The column was equilibrated and eluted with $0.05 \mathrm{M}$ ammonium carbonate. Fractions No. $11-14(14.6 \mathrm{ml}$ each) were collected. The solvent was evaporated off in vacuo and $\mathrm{MeOH}(2 \mathrm{ml})$ was added to the residue. After removal of insoluble material by filtration, ether $(10 \mathrm{ml})$ was added to the filtrate to form a precipitate, which was collected by filtration and washed with ether to give Boc-CCK $(27-32)$. Yield $85 \mathrm{mg}, \mathrm{mp} 240^{\circ} \mathrm{C}\left(\mathrm{dec}\right.$.), $[\alpha]_{\mathrm{D}}^{20}-11^{\circ}\left(c=1.4,1 \mathrm{~N} \mathrm{NH}_{4} \mathrm{OH}\right), R f^{1} 0.56, R f^{2} 0.13$. Amino acid ratio in an acid hydrolysate: Asp, 1.02; Gly, 1.01; Met, 1.96; Tyr, 1.01, $\mathrm{NH}_{3}, 0.88$ (average recovery, 86\%). BocCCK $(27-32)(60 \mathrm{mg})$ was added to a solution of TFA $(2 \mathrm{ml})$ containing thioanisole $(0.1 \mathrm{ml})$ at $0{ }^{\circ} \mathrm{C}$, followed by stirring for $1.5 \mathrm{~h}$. After the addition of ether $(50 \mathrm{ml})$, the resulting precipitate was collected by filtration and washed with ether to give crude CCK(27-32). This was purified by chromatography on a DEAE Sephadex A-25 column. The column $(1.2 \times 15 \mathrm{~cm})$ was eluted with a linear gradient of ammonium carbonate (from 0.1 to $0.7 \mathrm{M})$. Fractions $(13 \mathrm{ml}$ each) were checked for UV absorption at $254 \mathrm{~nm}$. Fractions No. 35-41 were collected and lyophilized. The lyophilization was repeated to give $\operatorname{CCK}(27-32)$ as a hygroscopic powder. Yield $20 \mathrm{mg}\left(37^{\circ}\right), \mathrm{mp} 170-175^{\circ} \mathrm{C}$ (dec.), $[\alpha]_{\mathrm{D}}^{20}-8.0^{\circ}\left(c=1.1, \mathrm{H}_{2} \mathrm{O}\right), R f^{1} 0.27, R f^{2} 0.12$. IR $v_{\max }^{\mathrm{KBr}} \mathrm{cm}^{-1}: 1050\left(\mathrm{SO}_{3}\right)$. Amino acid ratio in an acid hydrolysate: Asp, 1.01; Gly, 0.99; Met, 1.98; Tyr, 1.02; $\mathrm{NH}_{3}, 0.89$ (average recovery, 88\%). Anal. Calcd for $\mathrm{C}_{36} \mathrm{H}_{46} \mathrm{~N}_{7} \mathrm{NaO}_{13} \mathrm{~S}_{3} \cdot \mathrm{NH}_{3} \cdot 2.5 \mathrm{H}_{2} \mathrm{O}: \mathrm{C}, 44.76 ; \mathrm{H}, 5.63 ; \mathrm{N}, 11.60$. Found: $\mathrm{C}, 45.01 ; \mathrm{H}, 5.97 ; \mathrm{N}, 11.38$.

Boc-Asp(OBzl)-Ocp - 2,4,5-Trichlorophenol (4.94 g) and DCC (5.42 g) were added to a solution of BocAsp $(\mathrm{OBzl})-\mathrm{OH}^{14)}(8.08 \mathrm{~g})$ in dichloromethane $(50 \mathrm{ml})$ under cooling with ice, and the mixture was stirred at $7-8^{\circ} \mathrm{C}$ overnight. After removal of dicyclohexylurea by filtration, the solvent was evaporated off in vacuo. The residue was recrystallized from AcOEt-petroleum ether. Yield $8.4 \mathrm{~g}\left(66^{\circ} \%\right), \mathrm{mp} 82-83^{\circ} \mathrm{C},[\alpha]_{\mathrm{D}}^{21}-29.1^{\circ}(c=1$, DMF $)$. Anal. Calcd for $\mathrm{C}_{22} \mathrm{H}_{22} \mathrm{Cl}_{3} \mathrm{NO}_{6}: \mathrm{C}, 52.56 ; \mathrm{H}, 4.41 ; \mathrm{N}, 2.79$. Found: $\mathrm{C}, 52.75 ; \mathrm{H}, 4.36 ; \mathrm{N}, 2.68$.

Boc-Asp(OBzl)-Tyr-OBzl (VII) - This compound was obtained from H-Tyr-OBzl-TsOH ${ }^{11}$ and Boc-Asp- $-(\mathrm{OBzl})-\mathrm{OCp}$ according to the procedure described for $\mathrm{I}$. The crude product was purified by silica gel column chromatography with $\mathrm{CHCl}_{3}-\operatorname{AcOEt}(3: 1)$ as the eluent and crystallized from ether-petroleum ether to give a white powder. Yield $81 \%$, mp $101-102{ }^{\circ} \mathrm{C},[\alpha]_{D}^{21}-10.8^{\circ}(c=1$, AcOEt $), R f^{6} 0.47, R f^{7} 0.54$. Anal. Calcd for $\mathrm{C}_{32} \mathrm{H}_{36} \mathrm{~N}_{2} \mathrm{O}_{8}$ : C, 66.65; H, 6.29; N, 4.86. Found: C, 66.39; H, 6.31; N, 4.88.

Adoc-Arg(Adoc) $)_{2}$-Asp(OBzl)-Tyr-OBzl (VIII) - Compound VII ( $865 \mathrm{mg}$ ) was treated with TFA in the same manner as described for the deprotection of $I$ in the synthesis of IV. After evaporation of the TFA in vacuo, the residue was washed with ether and dried over $\mathrm{KOH}$ in vacuo to give $\mathrm{H}-\mathrm{Asp}(\mathrm{OBzl})-\mathrm{Tyr}-\mathrm{OBzl} \cdot \mathrm{TFA}$ (567 mg). From this compound and $\mathrm{Adoc}-\mathrm{Arg}(\mathrm{Adoc})_{2}-\mathrm{OSu},{ }^{12)} \mathrm{VIII}$ was obtained according to the procedure described for I. Crude VIII was purified by silica gel column chromatography with AcOEt-CHCl $\mathrm{CH}_{3}(1: 1)$ as the eluent and crystallized from ether-petroleum ether. Yield $44 \%$, mp $78-85^{\circ} \mathrm{C}$ (dec.) $[\alpha]_{\mathrm{D}}^{20}-13.6^{\circ}(c=1, \mathrm{MeOH}), R f^{6} 0.61, R f^{7} 0.39$. Anal. Calcd for $\mathrm{C}_{66} \mathrm{H}_{82} \mathrm{~N}_{6} \mathrm{O}_{13}: \mathrm{C}, 67.90 ; \mathrm{H}, 7.08 ; \mathrm{N}, 7.20$. Found: $\mathrm{C}, 67.63 ; \mathrm{H}, 7.37 ; \mathrm{N}, 7.03$.

Adoc-Arg(Adoc) $)_{2}$-Asp-Tyr-OH (IX) - A solution of VIII (413 mg) in $\mathrm{MeOH}(50 \mathrm{ml})$ was hydrogenated under the pressure of $40 \mathrm{psi}$ over a palladium catalyst (palladium black, $50 \mathrm{mg}$ ) at room temperature for $8 \mathrm{~h}$ using a Parr hydrogenation apparatus. After removal of the catalyst, the solvent was evaporated off in vacuo and the residue was crystallized from AcOEt-ether. Yield $250 \mathrm{mg}\left(72^{\circ} \%\right), \mathrm{mp} 178-182^{\circ} \mathrm{C}(\mathrm{dec}$. $),[\alpha]_{\mathrm{D}}^{20}+8.9^{\circ}(c=1, \mathrm{AcOEt}), R f^{2} 0.81, R f^{4}$ 0.71. Amino acid ratio in an acid hydrolysate: Arg, 1.00; Asp, 0.98, Tyr, 1.02 (average recovery, $90 \%$ ). Anal. Calcd for $\mathrm{C}_{52} \mathrm{H}_{69} \mathrm{~N}_{6} \mathrm{O}_{12} \cdot 2 \mathrm{H}_{2} \mathrm{O}: \mathrm{C}, 62.07 ; \mathrm{H}, 7.31 ; \mathrm{N}, 8.35$. Found: C, 62.13; H, 7.36; N, 8:23.

CCK(25-27) [H-Arg-Asp-Tyr $\left(\mathrm{SO}_{3}{ }^{-}\right)-\mathbf{O H}$ ] C Compound IX was sulfated then treated with aqueous sodium carbonate in the same manner as described for CCK(27-32). Water was evaporated off in vacuo, the residue was extracted with $\mathrm{MeOH}$, and then the extract was concentrated in vacuo to give crude protected CCK(25-27). This material was deprotected and the resulting crude $\operatorname{CCK}(25-27)$ was purified according to the procedure described for CCK (27-32), except that the DEAE Sephadex A-25 column was eluted with a linear gradient of ammonium carbonate from 0.01 to $0.1 \mathrm{M}$. Yield $65 \%, \mathrm{mp} 190-205^{\circ} \mathrm{C}(\mathrm{dec}$. $),[\alpha]_{365}^{20}-5.5^{\circ}\left(c=0.5, \mathrm{H}_{2} \mathrm{O}\right), R f^{1} 0.08, R f^{4} 0.17$. IR $v_{\max }^{\mathrm{KBr}} \mathrm{cm}^{-1}: 1045\left(\mathrm{SO}_{3}\right)$. Amino acid ratio in an acid hydrolysate: Arg, 1.01; Asp, 0.98; Tyr, 1.01 (average recovery, $84 \%$ ). 
Nine other C-terminal fragment peptides of CCK were prepared analogously. The physical propertiẹs are as follows.

$\mathrm{CCK}(27-31)\left[\mathrm{H}-\mathrm{Tyr}\left(\mathrm{SO}_{3}{ }^{-}\right)-\mathrm{Met}-\mathrm{Gly}-\mathrm{Trp}-\mathrm{Met}-\mathrm{OH}\right]: \operatorname{mp~} 140-145^{\circ} \mathrm{C}(\mathrm{dec}),.[\alpha]_{365}^{20}+3^{\circ}\left(c=0.1, \mathrm{H}_{2} \mathrm{O}\right), R f^{1}$ 0.43, $R f^{2}$ 0.09. IR $v_{\max }^{\mathrm{KBr}} \mathrm{cm}^{-1}: 1050\left(\mathrm{SO}_{3}\right)$. Amino acid ratio in an acid hydrolysate: Gly, 1.01; Met, 1.99; Tyr, 1.00; $\mathrm{NH}_{3}, 0.92$ (average recovery, 83\%). Anal. Calcd for $\mathrm{C}_{32} \mathrm{H}_{42} \mathrm{~N}_{6} \mathrm{O}_{10} \mathrm{~S}_{2} \cdot \mathrm{NH}_{3} \cdot 3.5 \mathrm{H}_{2} \mathrm{O}: \mathrm{C}, 45.38 ; \mathrm{H}, 6.19 ; \mathrm{N}, 11.58$. Found: C, 45.15; H, 6.35; N, 11.92 .

$\mathrm{CCK}(27-31)$ amide $\left[\mathrm{H}-\mathrm{Tyr}\left(\mathrm{SO}_{3}{ }^{-}\right)-\mathrm{Met}-\mathrm{Gly}-\mathrm{Trp}-\mathrm{Met}-\mathrm{NH}_{2}\right]: \operatorname{mp} \quad 160-166^{\circ} \mathrm{C} \quad(\mathrm{dec}),.[\alpha]_{\mathrm{D}}^{20}+22^{\circ} \quad(c=1$, $\mathrm{MeOH}), R f^{1} 0.62, R f^{2} 0.35$. IR $v_{\max }^{\mathrm{KBr}} \mathrm{cm}^{-1}: 1050\left(\mathrm{SO}_{3}\right)$. Amino acid ratio in an acid hydrolysate: Gly, 1.05; Met, 1.95 ; Tyr, 1.00; $\mathrm{NH}_{3}, 1.24$ (average recovery, 81\%). Anal. Calcd for $\mathrm{C}_{32} \mathrm{H}_{43} \mathrm{~N}_{7} \mathrm{O}_{9} \mathrm{~S}_{3} \cdot 3 \mathrm{H}_{2} \mathrm{O}: \mathrm{C}, 46.87 ; \mathrm{H}, 6.02 ; \mathrm{N}, 11.96$. Found: C, 46.74; H, 5.89; N, 12.04 .

$\mathrm{CCK}(27-30)\left[\mathrm{H}-\mathrm{Tyr}\left(\mathrm{SO}_{3}{ }^{-}\right)-\mathrm{Met}-\mathrm{Gly}-\mathrm{Trp}-\mathrm{OH}\right]: \operatorname{mp} 67-75^{\circ} \mathrm{C}$ (soften), $105-112^{\circ} \mathrm{C}\left(\mathrm{dec}\right.$ ), $[\alpha]_{\mathrm{D}}^{21}-10^{\circ}$ $\left(c=0.1,1 \mathrm{~N} \mathrm{NH}\right.$ OH), $R f^{1} 0.36, R f^{2} 0.06$. IR $v_{\max }^{\mathrm{KBr}} \mathrm{cm}^{-1}: 1050\left(\mathrm{SO}_{3}\right)$. Amino acid ratio in an acid hydrolysate: Gly, 0.99; Met, 0.97; Tyr, 1.03; $\mathrm{NH}_{3}, 0.95$ (average recovery, $90 \%$ ). Anal. Calcd for $\mathrm{C}_{27} \mathrm{H}_{33} \mathrm{~N}_{5} \mathrm{O}_{9} \mathrm{~S}_{2} \cdot \mathrm{NH}_{3} \cdot 2 \mathrm{H}_{2} \mathrm{O}: \mathrm{C}, 47.08$; H, 5.85; N, 12.20. Found: C, 46.92; H, 5.46; N, 11.88 .

$\mathrm{CCK}(27-30)$ amide $\left[\mathrm{H}-\mathrm{Tyr}\left(\mathrm{SO}_{3}{ }^{-}\right)-\mathrm{Met}-\mathrm{Gly}-\mathrm{Trp}-\mathrm{NH}_{2}\right]: \operatorname{mp} \quad 194-197^{\circ} \mathrm{C} \quad(\mathrm{dec}),.[\alpha]_{\mathrm{D}}^{20}+2^{\circ} \quad(c=0.1,1 \mathrm{~N}$ $\left.\mathrm{NH}_{4} \mathrm{OH}\right),[\alpha]_{365}^{20}+12^{\circ}\left(c=0.1,1 \mathrm{~N} \mathrm{NH} \mathrm{NH}_{4} \mathrm{OH}\right), R f^{1} 0.44, R f^{2} 0.15$. IR $v_{\max }^{\mathrm{KBr}} \mathrm{cm}^{-1}: 1050\left(\mathrm{SO}_{3}\right)$. Amino acid ratio in an acid hydrolysate: Gly, 0.95; Met, 1.01; Tyr, 1.02; $\mathrm{NH}_{3}, 1.02$ (average recovery, 89\%). Anal. Calcd for $\mathrm{C}_{27} \mathrm{H}_{34} \mathrm{~N}_{6} \mathrm{O}_{8} \mathrm{~S}_{2} \cdot 2.5 \mathrm{H}_{2} \mathrm{O}: \mathrm{C}, 47.70 ; \mathrm{H}, 5.78 ; \mathrm{N}, 12.36$. Found: $\mathrm{C}, 47.66 ; \mathrm{H}, 5.58 ; \mathrm{N}, 12.51$.

$\mathrm{CCK}(27-29)\left[\mathrm{H}-\mathrm{Tyr}\left(\mathrm{SO}_{3}{ }^{-}\right)-\mathrm{Met}-\mathrm{Gly}-\mathrm{OH}\right]: \operatorname{mp~} 178-182^{\circ} \mathrm{C}(\mathrm{dec}),.[\alpha]_{\mathrm{D}}^{22}+6^{\circ}\left(c=1, \mathrm{H}_{2} \mathrm{O}\right), R f^{1} 0.3, R f^{2} 0.02$. IR $v_{\max }^{\mathrm{KBr}} \mathrm{cm}^{-1}: 1050\left(\mathrm{SO}_{3}\right)$. Amino acid ratio in an acid hydrolysate: Gly, 0.99; Met, $1.02 ; \mathrm{Tyr}, 0.99 ; \mathrm{NH}_{3}, 0.99$ (average recovery, $89 \%$ ). Anal. Calcd for $\mathrm{C}_{16} \mathrm{H}_{23} \mathrm{~N}_{3} \mathrm{O}_{8} \mathrm{~S}_{2} \cdot \mathrm{NH}_{3} \cdot \mathrm{H}_{2} \mathrm{O} ; \mathrm{C}, 39.66 ; \mathrm{H}, 5.82 ; \mathrm{N}, 11.56$. Found: C, 39.78; $\mathrm{H}$, 5.94; N, 11.57

$\mathrm{CCK}(27-29)$ amide $\left[\mathrm{H}-\mathrm{Tyr}\left(\mathrm{SO}_{3}{ }^{-}\right)-\mathrm{Met}-\mathrm{Gly}-\mathrm{NH}_{2}\right]: \operatorname{mp~} 124-127^{\circ} \mathrm{C}(\mathrm{dec}),.[\alpha]_{\mathrm{D}}^{22}+25^{\circ}\left(c=1, \mathrm{H}_{2} \mathrm{O}\right), R f^{1} 0.40$, $R f^{2}$ 0.06. IR $v_{\max }^{\mathrm{KBr}} \mathrm{cm}^{-1}: 1050\left(\mathrm{SO}_{3}\right)$. Amino acid ratio in an acid hydrolysate: Gly, 0.99; Met, 1.02; Tyr, $0.99 ; \mathrm{NH}_{3}$, 1.05 (average recovery, 98\%). Anal. Calcd for $\mathrm{C}_{16} \mathrm{H}_{26} \mathrm{~N}_{4} \mathrm{O}_{8} \mathrm{~S}_{2} \cdot \mathrm{H}_{2} \mathrm{O}: \mathrm{C}, 41.19 ; \mathrm{H}, 5.61 ; \mathrm{N}, 12.00$. Found: C, 41.29; $\mathrm{H}$, $5.64 ; \mathrm{N}, 12.13$

$\mathrm{CCK}(26-27)\left[\mathrm{H}-\mathrm{Asp}-\mathrm{Tyr}\left(\mathrm{SO}_{3}{ }^{-}\right)-\mathrm{OH}\right]: \mathrm{mp} 122-126^{\circ} \mathrm{C}(\mathrm{dec}),.[\alpha]_{\mathrm{D}}^{21}+5.2^{\circ}\left(c=1, \mathrm{H}_{2} \mathrm{O}\right), R f^{1} 0.08, R f^{2} 0.01$, $R f^{4} 0.21$. IR $v_{\max }^{\mathrm{KBr}} \mathrm{cm}^{-1}: 1050\left(\mathrm{SO}_{3}\right)$. Amino acid ratio in an acid hydrolysate: Asp, $0.98 ; \mathrm{Tyr}, 1.01 ; \mathrm{NH}_{3}, 2.02$ (average recovery, $90 \%$ ). Anal. Calcd for $\mathrm{C}_{13} \mathrm{H}_{16} \mathrm{~N}_{2} \mathrm{O}_{9} \mathrm{~S} \cdot 2 \mathrm{NH}_{3} \cdot 0.5 \mathrm{H}_{2} \mathrm{O}: \mathrm{C}, 37.23 ; \mathrm{H}, 5.53 ; \mathrm{N}, 13.36$. Found: C, 37.45; H, 5.37; $\mathrm{N}, 13.02$.

$\mathrm{CCK}(26-27)$ amide $\left[\mathrm{H}-\mathrm{Asp}-\mathrm{Tyr}\left(\mathrm{SO}_{3}{ }^{-}\right)-\mathrm{NH}_{2}\right]: \mathrm{mp} 72-77^{\circ} \mathrm{C}$ (soften), $128-130^{\circ} \mathrm{C}(\mathrm{dec}),[\alpha]_{\mathrm{D}}^{21}+15.6^{\circ}(c=$ $0.5), R f^{1} 0.14, R f^{2} 0.01, R f^{4} 0.29$. IR $v_{\max }^{\mathrm{KBr}} \mathrm{cm}^{-1}: 1050\left(\mathrm{SO}_{3}\right)$. Amino acid ratio in an acid hydrolysate: Asp, 0.99 ; Tyr, 0.99; $\mathrm{NH}_{3}, 2.03$ (average recovery, 88\%). Anal. Calcd for $\mathrm{C}_{13} \mathrm{H}_{17} \mathrm{~N}_{3} \mathrm{O}_{8} \mathrm{~S} \cdot \mathrm{NH}_{3} \cdot 0.5 \mathrm{H}_{2} \mathrm{O}: \mathrm{C}, 38.90 ; \mathrm{H}, 5.27$; N,13.96. Found: C, 38.99; H, 5.20; N, 13.78 .

$\mathrm{CCK}(25-27)$ amide $\left[\mathrm{H}-\mathrm{Arg}-\mathrm{Asp}-\mathrm{Tyr}\left(\mathrm{SO}_{3}{ }^{-}\right)-\mathrm{NH}_{2}\right]: \operatorname{mp} 205-215^{\circ} \mathrm{C}(\mathrm{dec}),.[\alpha]_{\mathrm{D}}^{20}+12.6^{\circ}\left(c=0.46, \mathrm{H}_{2} \mathrm{O}\right), R f^{1}$ $0.11, R f^{4} 0.21$. IR $v_{\max }^{\mathrm{KBr}} \mathrm{cm}^{-1}: 1050\left(\mathrm{SO}_{3}\right)$. Amino acid ratio in an acid hydrolysate: Arg, 0.99; Asp, 0.99; Tyr, 1.03; $\mathrm{NH}_{3}, 1.10$ (average recovery, $92 \%$ ).

Acknowledgment We are grateful to Dr. T. Nose, general manager of the Pharmaceuticals Research Center, Kanebo Ltd., for his encouragement during this investigation, and Mr. H. Yoshidome, Development Laboratories, Kanebo Ltd., for elemental analyses.

\section{References and Notes}

1) The customary $L$ indication for amino acid residues is omitted. Standard abbreviations for amino acids and their derivatives are those recommended by the IUPAC-IUB Commission on Biochemical Nomenclature [Biochemistry, 5, 2485 (1966); 6, 362 (1967); 11, 1726 (1972)]. Other abbreviations used are: Boc, tertbutyloxycarbonyl; Adoc, adamantyl-1-oxycarbonyl; OCp, 2,4,5-trichlorophenyl ester; OSu, Nhydroxysuccinimido ester; OMe, methyl ester; $\mathrm{OBu}^{t}$, tert-butyl ester; OBzl, benzyl ester; DCC, dicyclohexylcarbodiimide; DMF, dimethylformamide; TFA, trifluoroacetic acid; AcOEt, ethyl acetate; AcOH, acetic acid; $\mathrm{MeOH}$, methanol; $n$-PrOH, 1-propanol; $n$-BuOH, 1-butanol; HOBt, 1-hydroxybenzotriazole.

2) G. Zetler, Neuropharmacology, 19, 415 (1980).

3) K. Iuchi, M. Nitta, K. Ito, Y. Morimoto and G. Tsukamoto, Chem. Pharm. Bull., 34, 115 (1986).

4) T. Kádár, A. Pesti, B. Penke, G. Tóth, M. Zarándi and G. Telegdy, Neuropharmacology, 22, 1223 (1983).

5) J. N. Crawley, S. St-Pierre and P. Gaudreau, J. Pharmacol. Exp. Ther., 230, 438 (1984).

6) W. Grassmann and E. Wünsh, Chem. Ber., 91, 449 (1958).

7) P. H. Bentley, H. Gregory, A. H. Laird and J. S. Morley, J. Chem. Soc., 1964, 6130.

8) H. Peter, M. Brugger, J. Schreiber and A. Eschenmoser, Helv. Chim. Acta, 46, 577 (1963).

9) Y. Wolman, A. Schejter and M. Sokolovsky, J. Am. Chem. Soc., 94, 1720 (1972). 
10) M. A. Ondetti, J. Pluščec, E. F. Sabo, J. T. Sheehan and N. Williams, J. Am. Chem. Soc., 92,195 (1970).

11) L. Zervas, M. Winitz and J. P. Greenstein, J. Org. Chem., 22, 1515 (1957).

12) G. Jäger and R. Geiger, Chem. Ber., 103, 1727 (1970).

13) Y. Mori and H. Yajima, Chem. Pharm. Bull., 24, 2781 (1976).

14) E. Bayer, G. Jung and H. Hagenmaier, Tetrahedron, 24, 4853 (1968). 